\title{
Stock Markets Development in Sub-Saharan Africa: Business Regulations, Governance and Fiscal Policy
}

\author{
Kofi B. Afful ${ }^{1} \&$ Kofi F. Asiedu ${ }^{2}$ \\ ${ }^{1}$ Ghana Institute of Management and Public Administration (GGIMPA), Achimota, Accra, Ghana \\ ${ }^{2}$ GGIMPA Consultancy Services, Ghana Institute of Management and Public Administration (GGIMPA), Ghana \\ Correspondence: Kofi Fred Asiedu, GGIMPA Consultancy Services, Ghana Institute of Management and Public \\ Administration (GGIMPA), P.O. Box AH50, Achimota, Accra, Ghana. Tel: 233-2-4482-9518. E-mail: \\ fkasiedu@yahoo.com orkasiedu@gimpa.edu.gh
}

Received: October 22, 2013

Accepted: November 6, $2013 \quad$ Online Published: December 23, 2013

doi:10.5539/ijef.v6n1p15

URL: http://dx.doi.org/10.5539/ijef.v6n1p15

\begin{abstract}
This study examines the effectiveness of the state in stimulating stock market activity in sub-Saharan Africa (SSA) using fiscal policy, governance quality and stock market as the main determinant variables. Using annual data from six selected sub-Saharan African economies and employing a dynamic panel data estimating technique, we find that government effectiveness stimulates capitalization while business regulations decrease it in SSA. In addition, we find that final consumption expenditure, interest rate spread and credit to the state increase capitalization whereas credit to the private sector and inflation had adverse effects. With respect to business regulations, our study reveals that starting a business, closing it and enforcing contracts engender stock market activity in SSA. Among the several variables that stimulate stock market activity; only foreign direct investment (FDI) did increase capitalization. Thus, the study concludes that since not all government institutions and business regulations are critical to stock market development, various governments should be careful and selective in their economic stimulants if they want to develop their stock markets.
\end{abstract}

Keywords: governance, fiscal policy, stock markets, business regulations, sub-Saharan Africa

\section{Introduction}

A review of current development literature shows that Africa is still classified as one of the most underdeveloped continents with many countries on the continent not likely to meet the UNDP Millennium Development Goals (MDGs). The MDGs, set in 2006 by the United Nations Development Program (UNDP), are the world's time-bound targets for overcoming extreme poverty and extending human freedom (HD, 2006). The goals range from eradicating extreme poverty and hunger to developing a global partnership for development. A study of the financial systems of most countries shows that the financial goals set by these countries are reminiscent of the MDGs: improving savings to a strong regulatory environment and well designed safety nets for investors in the sub-region. Meeting financial goals in various countries, according to experts will be very difficult given the state of economic development and the level of financial indiscipline (Asiedu \& Afful, 2013). The situation is even pronounced in sub-Saharan Africa (SSA) where the financial environment is characterized by low savings; small and illiquid stock markets; dis-intermediation, fragmented market and informal financial system; inefficient clearing and payment system; lack of financial innovation; and weak regulatory environment and ill-designed safety nets (see Ncube, 2007 for full discussion). Other studies point out that the current pattern of economic growth is worrisome given the structure of most economies: young and growing population; infrastructure bottlenecks; high youth unemployment and high levels of subsistence economy (HDR, 2011; Irving, 2000). Thus, countries will need to engage in growth paths that generate jobs on a large scale to absorb the additional labor.

The woes plaguing SSA are supported by research that shows that despite years of structural transformation, the changes are not making the desired impact because they are not productivity-enhancing structural changes (HDR, 2011). According to these researchers, what is needed for the region is a structural transformation involving an increase in the share of high productivity manufacturing and modern services in output including efficient public and financial sectors accompanied by increase in agricultural productivity (Asiedu \& Afful 2013; HDR, 2011). Most economies in SSA have responded to these challenges by initiating measures to transform their economies 
including reforms of their financial sector. This has spurred on donors as well as development and trading partners to advocate the strengthening of domestic financial institutions, and the development of credible partnership with the private sector. Partly due to recommendations from foreign consultants and governments as well as the desire to be less dependent on external funding, African countries have continued developing their financial systems through the establishment and strengthening of their stock markets. The continuous development of such financial institutions was also a response to the 'perceived' failure of some of the suggested political and economic reforms as well as 'onerous' conditions tied to the assistance provided by international agencies (Agyeman-Duah, 2008; Fage, 2001). The hope was that these stock markets would help raise much needed long-term funds to finance the growth and development of Africa. Furthermore, it was anticipated that the markets would increase liquidity in the economy and provide financial independent to these countries: to some extent, African governments felt that stock markets would be a panacea for their financial needs.

However, as at 2012, apart from South Africa (SA), the average ratio of stock market capitalization to gross domestic product (GDP) in Sub-Saharan African (SSA) was less than 30\%. This same ratio for just one country in Asia, Malaysia, is approximately $148 \%$. This raises questions from stakeholders about whether these financial institutions can help lift Africa from its economic doldrums as initially intended. Afful \& Okeahalam (2006) and Asiedu \& Afful (2013) in their studies find that generally, SSA stock markets have been ineffective in raising capital for real sector investment as well as impacting positively on African economies. Irving (2000) earlier on even questioned whether these institutions have boosted development or just a costly irrelevance. It is therefore not out of place when Singh (1999) argued against stock market capitalism. Rather, he recommended the strengthening and expansion of banks and related financial institutions as he felt they would be of greater benefit to sub-Saharan economies rather than the current illiquid and thin stock markets with their sparse listed firms.

Having spent billions of dollars and scarce national resources to establish stock markets that have not fulfilled their underlying purpose, it is necessary to identify the challenges constraining their ability to raise the much needed development and investment capital and be relevant in the economic development of nations. It is therefore required to find policies and strategies to turn such exchanges into active, vibrant and successful financial markets such as that of the Johannesburg Stock Exchange (JSE). In the almost 20 years after the first few exchanges were established in SSA, most of them have less than 50 listed companies. Furthermore, market capitalization is concentrated among a few firms in Africa. For instance, Ashanti Goldfields and Tullow Oil Ltd. make up almost $90 \%$ of total market capitalization of the Ghana Stock Exchange (GSE). To put this into context, in 2006 the number of listed firms on the Malaysia stock exchange was approximately 1,027. This exceeded the total number of listed companies in SSA. Furthermore, in SSA, the most traded securities are treasury securities. Sovereign bonds and related financial instruments of SSA countries are rather issued in more developed financial markets such as in the United Kingdom (Stiglitz \& Rashid, 2013).

To address this, different remedial measures have been suggested. One of these has been the formulation of incentives for domestic firms desiring to list on SSA stock markets. Some of these incentives include tax holidays and access to domestic and foreign finance (GRA, 2013). However, after proffering such incentives for over five years, the number of firms listing on most SSA stock exchanges is stagnant or increasing at a very slow rate. For instance, despite the application of the government's incentives, there has been no new listed firm or IPO on the GSE since 2011. The pattern can be seen across a number of countries in Sub-Saharan Africa. Table 1 illustrates that in some years, the number of listed firms on SSA stock markets rather decreased. One implication of this is that the formulated incentives have failed or not met its expected objective. Some resulting concerns from this failure are whether the incentives are appropriate and whether the problem is really incentives.

This paper therefore takes a critical look at the financial environment of sub-Saharan economies and examines whether the surrounding domestic institutional environment and fiscal policies are the causative factors inhibiting stock market development in SSA. Specifically, the paper looks at all the factors inhibiting the growth of sub-Saharan Africa financial sector as discussed by Ncube (2007) and picks the last factor "weak regulatory environment and ill-designed safety nets" and critically examines its significance to the development of stock markets in SSA.

The rest of the paper includes a critical review of past literature and research in the field in section 2. Section 3 discusses the data and methodology used in the empirical analysis. It describes the pertinent features of the data and the appropriate analytical technique. The ensuing section discusses the empirical results. The last section summarizes the main findings, concludes and provides pertinent recommendations.

\section{Literature Review}

A review of literature shows that a significant number of past research have examined how institutional quality 
affect financial market development in developed and emerging economies. Such works include the seminal contributions of La Porta, Lopez de-Silanes, Sheifer \& Vishny (1997; 1998; 1999). Pistor et al. (2000) apply the propositions of La Porta et al. $(1997 ; 1998)$ to transition economies and find that legal institutions' effectiveness has a more significant impact on the development of both credit and equity markets. Beck et al. (2003) extend the analysis by using cross-country regressions on a sample of 70 former colonies and find that a country's legal systems and its initial endowments determine its financial development. Djankov, McLiesh \& Shleifer (2007) build on this and empirically find that creditor protection, legal system and information sharing institutions increase bank lending to the private sector. Other studies including Baltagi, Demetriades \& Law (2009), Holder (2007), Girma \& Shortland (2008) and Law \& Habibullah (2009) demonstrate that institutional quality is a statistically significant determinant of financial market development.

Other studies, Anayiotos \& Toroyan (2009), Cherif \& Gadzar (2006), Dahou et al., (2009), Okeahalm (2005) and Standley (2010) focus more on emerging and African economies and suggest that the legal and regulatory framework within which stock markets operate are critical for their development. They find that governance institutions are critical to non-African emerging economies. Such determinants also significantly influence the depth and maturity of financial markets. However, paucity of data for SSA has prevented a similar in-depth analysis for the continent. For instance, doing business indicators of World Bank (2013b) in SSA commenced in 2004 and this negates the use of a panel data set for an extended time period.

In terms of fiscal policy, past research has established a relationship between fiscal policy and stock markets in developed economies. Examples of such studies include: Afonso and Sousa (2011); Ardagna (2008); Darat (1988); Jansen et al. (2008); Razin (1990) and Unro (2007). All these studies conclude that stock prices increase during tight fiscal policies and vice versa and that the differences in countries are accounted for by the country's type of fiscal consolidations and initial conditions.

Lee (1992) and Shah (1984) widen the scope of inquiry on the relationship between fiscal policy and stock markets to include crowding out, inflation, interest rates and real activity. They find that revenue-based fiscal adjustments narrow financial market spreads more significantly as compared to expenditure-based adjustments. Consequently, they distinguish between revenue-financed and money-financed fiscal policy. This implies that the composition of fiscal spending determines the response of financial markets. They conclude that money-financed fiscal policy adversely affects stock markets and distorts asset markets since it can interfere with the pricing mechanism. For instance, excessive lending to the state by domestic banks increases the cost of borrowed funds and crowds out private borrowing (Akitoby \& Stratmann, 2008). When listed firms do not offer similar returns as substitutes to bank lending rates, they cannot attract much needed capital to grow and increase domestic stock market capitalization. Since 2002, annual bank lending rates in Ghana have hovered between $25 \%$ and $35 \%$. Only a few listed securities on the Ghana Stock Exchange (GSE) can offer similar annual returns. In SSA only few securities can offer such rates of return for more than a year while the bank lending rate has remained within the afore-mentioned range for almost a decade.

Other researchers find that the magnitude of the effect of fiscal policy on stock markets is determined by its relative efficiency (Ali \& Hasan, 2003; Laopodis, 2009). As such, more efficient stock markets are highly sensitive to unanticipated changes in fiscal policy. Inefficient stock markets do not seem to respond to both anticipated and unanticipated new information (Mountford \& Harald, 2009). Furthermore, efficient financial markets are highly sensitive to fiscal shocks. For instance, Afonso and Sousa (2012) and Chatziantoniou, Duffy and Ellis (2013) find that fiscal shocks have both direct and indirect effects on stock markets in developed economies. An implication of these findings is that fiscal policy affects only relatively efficient stock market.

In SSA, Yartey and Adjasi (2007) as well as Senbet and Otchere (2008) find a weak relationship between stock market development and fiscal policy. Their findings suggest that the inefficiencies of SSA stock markets are due to their manual clearing, settlement and trading systems as well as adverse ownership structures. These factors mentioned above in turn negatively affect the governance, legal and ownership features (Otchere, 2006). Thus these findings are in tandem with the school of thought that relatively efficient markets are more sensitive to fiscal policy.

Existing empirical research on the effects of the regulatory environment and well-designed safety nets on the operations of SSA stock markets are limited. However, the few studies analyzed show that efficient stock markets operating in appropriate regulatory and institutional systems encourage economic growth (Afful \& Okeahalam, 2006; Senbet \& Otchere, 2008). These empirical studies, however, did not critically review the effects of different facets of institutional quality on stock markets, neither do they examine whether the stunted development of SSA bourses is as a result of inappropriate business regulations. Furthermore, there is not much 
research on the role of the state, especially how the state can use fiscal policy tools to aid stock market development in SSA. This paper therefore seeks to bridge the afore-mentioned gaps in existing literature.

\section{Data and Methodology}

We pick our data from stock markets in SSA and exclude countries currently experiencing civil, ethnic or political strife in the region. Furthermore, countries in SSA that have undergone the afore-mentioned national problems within the period 1980 to 2010 are excluded from our sample. This is because data from such countries will most likely have white noise. This restricts the examined sample to Botswana, Ghana, Kenya, Mauritius, Nigeria and South Africa.

Table 1. Number of listed firms in selected SSA stock markets

\begin{tabular}{lcccccc}
\hline & Botswana & Ghana & Kenya & Mauritius & Nigeria & South Africa \\
\hline $\mathbf{2 0 0 0}$ & $17.34(16)$ & $9.81(22)$ & $10.35(57)$ & $31.69(40)$ & $7.54(195)$ & $165.95(616)$ \\
$\mathbf{2 0 0 1}$ & $17.60(16)$ & $8.82(22)$ & $8.91(57)$ & $25.01(40)$ & $10(194)$ & $130.01(542)$ \\
$\mathbf{2 0 0 2}$ & $23.67(18)$ & $9.87(24)$ & $9.35(57)$ & $24.94(40)$ & $9.35(195)$ & $134.81(450)$ \\
$\mathbf{2 0 0 3}$ & $27.13(19)$ & $14.33(25)$ & $19.20(51)$ & $30.11(40)$ & $10.7(200)$ & $157.86(426)$ \\
$\mathbf{2 0 0 4}$ & $24.05(18)$ & $22.93(29)$ & $25.26(47)$ & $34.14(41)$ & $13.2(207)$ & $176.23(403)$ \\
$\mathbf{2 0 0 5}$ & $23.33(18)$ & $21.27(30)$ & $28.03(47)$ & $38.54(42)$ & $15.8(214)$ & $209.01(388)$ \\
$\mathbf{2 0 0 6}$ & $27.14(18)$ & $12.04(32)$ & $41.01(51)$ & $46.54(41)$ & $18.4(202)$ & $239.13(401)$ \\
$\mathbf{2 0 0 7}$ & $38.81(18)$ & $11.47(32)$ & $46.96(51)$ & $59.26(90)$ & $35.9(212)$ & $265.68(422)$ \\
$\mathbf{2 0 0 8}$ & $34.05(20)$ & $9.70(35)$ & $42.33(53)$ & $51.66(89)$ & $35.6(213)$ & $225.71(379)$ \\
$\mathbf{2 0 0 9}$ & $33.45(20)$ & $10.15(35)$ & $33.60(55)$ & $44.33(89)$ & $21.7(214)$ & $210.96(363)$ \\
$\mathbf{2 0 1 0}$ & $29.07(21)$ & $9.49(35)$ & $38.37(55)$ & $58.32(86)$ & $21(215)$ & $252.21(360)$ \\
$\mathbf{2 0 1 1}$ & $23.30(23)$ & $7.90(36)$ & $30.35(58)$ & $57.80(86)$ & $16.65(196)$ & $209.61(355)$ \\
\hline
\end{tabular}

Source: World Bank, 2013. Note: The number of listed companies is in parentheses.

Table 1 presents data on the market capitalization as a ratio of GDP as well as the number of listed companies for each country. The table indicates that market capitalization as a ratio of GDP increased from $17.34 \%$ in 2000 to 23.3\% in 2011 for Botswana: the number of listed companies increased by only 5 in the examined time period. In Ghana, the ratio of capitalization to GDP decreased from $9.81 \%$ to $7.9 \%$ within the afore-mentioned years, despite the doubling of the number of listed firms. In Kenya, the number of listed companies remained almost the same while its capitalization to GDP ratio tripled. Mauritius more than doubled its number of listed companies and its capitalization to GDP ratio. However, in Nigeria, the ratio doubled but the number of listed companies only increased by one. In comparison with the above-mentioned SSA countries, South Africa is an outlier. Its capitalization to GDP ratio increased from $165.95 \%$ to $209.61 \%$ and accounts for more than $80 \%$ of total market capitalization in SSA. In contrast, its number of listed companies decreased from 616 to 355 within the examined time period. Apart from being the largest, the Johannesburg Stock Exchange (JSE) is also the most active stock market on the continent.

As almost all SSA stock markets were established in the 1990s, there is insufficient time-series data to use time-series regression analysis for each country. Therefore, we use a panel data set as it is a more inclusive approach compared with an autoregressive model. Our data is constructed from the Africa Indicators, World Development Indicators and World Governance Indicators databases. These were obtained from World Bank (2013a; 2013b; 2013c).

The selection of variables used in this study is guided by Akitoby and Stratmann (2008), Ardagna (2011) and Okeahalam (2005). A correlation analysis for each SSA country is used as a first-step to assess the relation between the dependent and independent variables. These are presented in tables 2 to 7 . Table A1 presents the results of a correlation test for multicollinearity between business regulation and governance variables. The empirical results of the first and second regression analysis are found in tables 8 and 10 respectively.

The variables used in the first regression model are divided into three main categories, namely: fiscal policy, governance quality and stock market data. The second regression model uses variables on business regulations, 
fiscal policy and stock markets. Various fiscal policy variables such as credit to government and state-owned enterprises; and public sector gross domestic fixed investment (GDFI) are used in the equation. The data on institutional quality presents information on different dimensions of governance. These include control of corruption; government effectiveness; regulatory quality; and rule of law. For the stock market, the main variable is capitalization. As most SSA bourses are relatively inactive, illiquid and characterized by thin trading, their turnover indicators are inappropriate for regression analysis. The variables considered for business regulation are closing a business; enforcing contracts; starting a business; and trading across borders.

The first regression model covers the time period 1996 to 2010. This is because the governance variables were only available for the afore-mentioned time period. Compilation of the governance indicators commenced in 1996 in most countries, with the business regulations data for the second regression analysis also commencing in 2004. Consequently, the panel dataset for that empirical analysis was for the time period 2004 to 2011 . All variables included in the regression models were first tested for non-stationarity using the augmented Dickey-Fuller test. They were found to be co-integrated of the first order. The study uses a $5 \%$ significance level.

\section{Empirical Results}

Before analyzing the relationship between market capitalization on one hand and, governance and business regulation on the other, a correlation coefficient test is used to explore the relation between fiscal policy, governance and stock markets for each examined SSA country. Tables 1 to 6 present the correlation coefficients and their respective t-statistics. Coefficients with an asterisk are significant at a $5 \%$ significance level. The results of the correlation analysis for each country are discussed hereafter.

\subsection{Botswana}

Table 2 presents the results of the correlation analysis for Botswana. It illustrates that in the afore-mentioned country, control of corruption increases the lending-deposit spread, bank credit to the state, bank credit to the private sector and public sector GDFI. Better control of corruption increases all the afore-mentioned variables. This may suggest that improvements in this governance institution, increases business confidence leading to increased lending to the state and private sector. With fewer leakages, such monies lent to government may be used for public sector GDFI (Akitoby \& Stratman, 2008).

Table 2. Correlation coefficient of panel data variables for Botswana

\begin{tabular}{|c|c|c|c|c|c|c|}
\hline & $\begin{array}{l}\text { Control of } \\
\text { corruption }\end{array}$ & $\begin{array}{l}\text { Government } \\
\text { effectiveness }\end{array}$ & $\begin{array}{c}\text { Regulatory } \\
\text { quality }\end{array}$ & Rule of law & $\begin{array}{l}\text { Stock market } \\
\text { capitalization }\end{array}$ & $\begin{array}{c}\text { Stock market } \\
\text { turnover }\end{array}$ \\
\hline $\begin{array}{l}\text { Final consumption } \\
\text { expenditure/ GDP }\end{array}$ & $0.25(0.97)$ & $0.02(0.08)$ & $-0.16(-0.62)$ & $0.15(0.58)$ & $-0.04(-0.17)$ & $-0.11(-0.40)$ \\
\hline Lending-deposit spread & $0.61 *(2.89)$ & $0.35(1.42)$ & -2.2914 & $0.48 *(2.04)$ & $0.85 *(5.93)$ & 1.4224 \\
\hline $\begin{array}{l}\text { Credit to government } \\
\text { and state-owned } \\
\text { enterprises/GDP }\end{array}$ & $0.55 *(2.46)$ & $0.19(0.73)$ & 1.9278 & $0.81 *(5.12)$ & $0.69 *(3.55)$ & $-0.05(-0.21)$ \\
\hline $\begin{array}{l}\text { Credit to private } \\
\text { sector/GDP }\end{array}$ & $0.68 *(3.44)$ & $0.44(1.82)$ & 2.0995 & $0.74 *(4.17)$ & $0.87 *(6.61)$ & $-0.42(-1.74)$ \\
\hline External debt/GDP & $0.39(1.60)$ & $0.12(0.47)$ & 3.1425 & $0.62 *(2.95)$ & $0.79 *(4.75)$ & $-0.21(-0.82)$ \\
\hline Inflation & $-0.24(-0.94)$ & $-0.30(-1.16)$ & $-0.03(-0.10)$ & $-0.17(-0.65)$ & $0.05(0.18)$ & $0.47(2.00)$ \\
\hline $\begin{array}{l}\text { Foreign direct } \\
\text { investment ( } \% \text { of GDP) }\end{array}$ & $-0.11(-0.43)$ & $0.03(0.10)$ & $0.01(0.03)$ & $-0.18(-0.69)$ & $0.05(0.18)$ & $0.14(0.52)$ \\
\hline Public GDFI & $0.68 *(3.44)$ & $0.44(1.82)$ & 2.0995 & $0.74 *(4.17)$ & $0.87 *(6.61)$ & $-0.42(-1.74)$ \\
\hline
\end{tabular}

Source: own computation. Note: Values with * beside them are significant at $5 \%$ significance level.

Government effectiveness did not correlate with any of the fiscal policy or stock market variables. Regulatory quality, however, decreased the spread, credit to the state and private sector, external debt and public GDFI. It may be inferred that improvements in regulations, its implementation and the state machinery decreased fiscal expenditure. One explanation of the fall in domestic bank lending and external debt may be that with a more effective government, the state is able to raise more revenue to become self-sufficient and less dependent on borrowed funds as suggested by Allen, Otchere \& Senbet (2011). 
However, the table illustrates that as rule of law improves in Botswana, the lending-deposit margin, credit to the state and private sector as well as external debt increase. Excluding the spread, the afore-mentioned variables respond positively to improvements in the rule of law. Possibly, better rule of law has a similar effect as improved control of corruption (Baltagi et al., 2009). The results further illustrate that an increase in the spread, credit to the private and public sectors, external debt and public sector GDFI increase stock market capitalization in Botswana. Despite the adverse effect of the spread on turnover, the results are similar to the findings of Afonso and Sousa (2012) on the effects of the fiscal policy variables on stock market development.

\subsection{Ghana}

Table 3 presents the results of the correlation analysis between selected variables for Ghana. It illustrates that in that country, an improvement in control of corruption decreases financial consumption expenditure, lending-deposit spread, credit to the public sector, external debt and inflation. The correlation analysis finds that regulatory quality decreases credit to the state, inflation and the lending-deposit spread. On the other hand, it increases FDI lending to the private sector and public sector GDFI. The table further demonstrates that an improvement in rule of law increases credit to the private sector and public sector GDFI. These findings confirm the recommendations of Dahou, Omar and Pfister (2009), which suggest the need for critical regulatory reforms in SSA to significantly stimulate financial market development on the continent. They further opine that such reforms cannot be achieved in a single leap. It will necessitate a planned sequential alteration and modification of institutional and policy frameworks. This may decrease the sometimes adverse effect of the combination of a new well-intended regulation with already existing laws.

The correlation analysis also implies that FDI and stock market capitalization are negatively related in Ghana. Possibly, these two could be substitutes. Also, turnover is negatively related to final consumption expenditure, lending-deposit spread; credit to government and inflation with credit to private sector, external debt, FDI and public GDFI correlating positively with turnover of firms.

Table 3. Correlation coefficient of panel data variables for Ghana

\begin{tabular}{|c|c|c|c|c|c|c|}
\hline & $\begin{array}{l}\text { Control of } \\
\text { corruption } \\
\end{array}$ & $\begin{array}{l}\text { Government } \\
\text { effectiveness }\end{array}$ & $\begin{array}{c}\text { Regulatory } \\
\text { quality }\end{array}$ & Rule of law & $\begin{array}{l}\text { Stock market } \\
\text { capitalization }\end{array}$ & $\begin{array}{c}\text { Stock market } \\
\text { turnover }\end{array}$ \\
\hline $\begin{array}{l}\text { Final consumption } \\
\text { expenditure/GDP }\end{array}$ & 1.6343 & $-0.36(-1.47)$ & $-0.39(-1.59)$ & $0.27(1.06)$ & $0.14(0.53)$ & $-0.38(-1.51)$ \\
\hline Lending-deposit spread & 1.4763 & $-0.42(-1.71)$ & 1.17 & $0.25(0.96)$ & $0.02(0.09)$ & 1.2402 \\
\hline $\begin{array}{l}\text { Credit to government } \\
\text { and state-owned } \\
\text { enterprises/GDP }\end{array}$ & 4.2201 & 1.3122 & 3.928 & $-0.24(-.92)$ & $0.50(2.13)$ & 4.8636 \\
\hline $\begin{array}{l}\text { Credit to private sector } \\
\text { /GDP }\end{array}$ & $0.38(1.55)$ & $0.26(1.01)$ & $0.67 *(3.41)$ & $0.61 *(2.89)$ & $-0.43(-1.79)$ & $0.68 *(3.48)$ \\
\hline External debt/GDP & 2.346 & 2.08 & $-0.13(-0.48)$ & $0.18(0.67)$ & $0.34(1.34)$ & $0.77 *(4.47)$ \\
\hline Inflation & 1.2402 & $-0.38(-1.53)$ & 1.7507 & $0.44(1.86)$ & $-0.07(-0.27)$ & 2.698 \\
\hline $\begin{array}{l}\text { Foreign direct } \\
\text { investment ( } \% \text { of GDP) }\end{array}$ & $0.80 *(4.94)$ & $0.59 *(2.75)$ & $0.79 *(4.78)$ & $0.25(0.95)$ & 1.3014 & $0.86^{*}(6.29)$ \\
\hline Public GDFI & $0.38(1.55)$ & $0.26(1.01)$ & $0.67 *(3.41)$ & $0.61 *(2.89)$ & $-0.43(-1.79)$ & $0.68 *(3.48)$ \\
\hline
\end{tabular}

Source: own computation. Note: Values with * beside them are significant at $5 \%$ significance level.

\subsection{Kenya}

Table 4 presents the correlation coefficients and their respective significance tests for Kenya. It finds that control of corruption has no effect on the selected governance and fiscal policy variables. However, as government effectiveness improves bank credit to the private sector decreases. Also, while regulatory quality narrows, the lending-deposit spread, credit to the state as well as inflation, it has minimal effect on external debt. In spite of this, it increases public sector GDFI. This is similar to the arguments of Law and Habibullah (2009) that suggest 
that control of corruption and improvement of the rule of law affect stock market development. Furthermore, in Kenya, we find the lending-deposit spread, credit to the state and inflation to have a negative effect on stock market capitalization whilst credit to the private sector and FDI increased capitalization. Stock market turnover was similarly affected by governance and fiscal policy variables. These results buttress the findings of Lee (1997) and Mountford \& Harald (2009) that report that external debt had no effect on capitalization, but rather increases turnover.

Table 4. Correlation coefficient of panel data variables for Kenya

\begin{tabular}{lcccccc}
\hline & $\begin{array}{c}\text { Control of } \\
\text { corruption }\end{array}$ & $\begin{array}{c}\text { Government } \\
\text { effectiveness }\end{array}$ & $\begin{array}{c}\text { Regulatory } \\
\text { quality }\end{array}$ & Rule of law & $\begin{array}{c}\text { Stock market } \\
\text { capitalization }\end{array}$ & $\begin{array}{c}\text { Stock market } \\
\text { turnover }\end{array}$ \\
\hline $\begin{array}{l}\text { Final consumption } \\
\text { expenditure/ GDP }\end{array}$ & $0.06(0.21)$ & $-0.27(-1.04)$ & $-0.21(-0.81)$ & $0.28(1.08)$ & $0.09(0.32)$ & $0.11(0.41)$ \\
$\begin{array}{l}\text { Lending-deposit spread } \\
\text { Credit to government }\end{array}$ & $-0.19(-0.71)$ & $0.43(1.78)$ & 1.668 & $-0.11(-0.43)$ & -4.6978 & 4.131 \\
$\begin{array}{l}\text { and state-owned } \\
\text { enterprises/GDP }\end{array}$ & $0.08(0.29)$ & $0.06(0.24)$ & 1.8414 & $0.25(0.96)$ & 6.0632 & 4.648 \\
$\begin{array}{l}\text { Credit to private } \\
\text { sector/GDP }\end{array}$ & $0.12(0.47)$ & 1.482 & $0.85 *(6.15)$ & $0.14(0.52)$ & $0.54 *(2.41)$ & $0.64 *(3.12)$ \\
$\begin{array}{l}\text { External debt / GDP } \\
\text { Inflation }\end{array}$ & $0.36(1.45)$ & $0.03(0.13)$ & 0.01 & $0.16(-0.61)$ & $0.47(2.00)$ & $0.60 *(2.80)$ \\
$\begin{array}{l}\text { Foreign direct } \\
\text { investment (\% of GDP) }\end{array}$ & $-0.15(-0.57)$ & $0.02(0.08)$ & $0.50(2.15)$ & $-0.28(-1.11)$ & $0.72 *(3.90)$ & $0.75 *(4.23)$ \\
\begin{tabular}{l} 
Public GDFI \\
\hline
\end{tabular} & $-0.15(-0.58)$ & $-0.26(-1.00)$ & $0.57 *(2.61)$ & $-0.17(0.61)$ & $0.20(0.75)$ & $0.33(1.33)$ \\
\hline
\end{tabular}

Source: own computation. Note: Values with * beside them are significant at $5 \%$ significance level.

\subsection{Mauritius}

Table 5. Correlation coefficient of panel data variables for Mauritius

\begin{tabular}{|c|c|c|c|c|c|c|}
\hline & $\begin{array}{l}\text { Control of } \\
\text { corruption }\end{array}$ & $\begin{array}{l}\text { Government } \\
\text { effectiveness }\end{array}$ & $\begin{array}{c}\text { Regulatory } \\
\text { quality }\end{array}$ & Rule of law & $\begin{array}{l}\text { Stock market } \\
\text { capitalization }\end{array}$ & $\begin{array}{c}\text { Stock market } \\
\text { turnover }\end{array}$ \\
\hline $\begin{array}{l}\text { Final consumption } \\
\text { expenditure/GDP }\end{array}$ & $0.11(0.43)$ & $0.74 *(4.15)$ & $0.60 *(2.84)$ & -1.1322 & $0.80 *(4.91)$ & $0.70 *(3.62)$ \\
\hline Lending-deposit spread & 1.9278 & $0.36(1.46)$ & $0.19(0.71)$ & $0.42(1.75)$ & $-0.19(-0.71)$ & $-0.05(-0.20)$ \\
\hline $\begin{array}{l}\text { Credit to government } \\
\text { and state-owned } \\
\text { enterprises / GDP }\end{array}$ & 1.2402 & $0.72 *(3.85)$ & $0.23(0.90)$ & $-0.02(-0.06)$ & $0.26(0.99)$ & $0.32(1.26)$ \\
\hline $\begin{array}{l}\text { Credit to private sector } \\
\text { /GDP }\end{array}$ & $-0.05(-0.17)$ & $0.90 *(7.78)$ & $0.81 *(5.13)$ & $-0.21(-0.80)$ & $0.61 *(2.88)$ & $0.69 *(3.60)$ \\
\hline External debt / GDP & $0.57 *(-2.25)$ & -2.133 & $0.22 *(2.56)$ & $0.34(-0.49)$ & $0.75 *(2.31)$ & $0.79 *(2.29)$ \\
\hline Inflation & $-0.16(-0.61)$ & $-0.09(-0.33)$ & $-0.27(-1.03)$ & $-0.25(-0.98)$ & $0.26(1.03)$ & $-0.04(-0.16)$ \\
\hline $\begin{array}{l}\text { Foreign direct } \\
\text { investment ( } \% \text { of GDP) }\end{array}$ & $0.33(1.32)$ & $0.42(1.71)$ & $0.50 *(2.18)$ & $-0.47(-2.01)$ & $0.61 *(2.85)$ & $0.43(1.78)$ \\
\hline Public GDFI & $0.63(-0.17)$ & -4.4793 & $0.43 *(2.56)$ & $0.35(-0.49)$ & $0.65 *(2.31)$ & $0.68 *(2.29)$ \\
\hline
\end{tabular}

Source: own computation. Note: Values with * beside them are significant at $5 \%$ significance level. 
Table 5 presents the results of the correlation analysis of selected pertinent variables for Mauritius. It illustrates that control of corruption decreased the lending-deposit spread and credit to government. However, it increased external debt as accountability and judicious use of such borrowed funds improved. Better government effectiveness increased final consumption expenditure, credit to the state and to the private sector. However, improved state effectiveness reduced external debt and public GDFI. This may be because the state would require less external funds as it becomes more effective at domestic revenue collection as well as improving both external and local private investment. Improvements in regulatory quality result in a rise in final consumption expenditure, credit to the private sector, external debt, FDI and public sector GDFI. The results indicate that improved rule of law decreases final consumption expenditure. While better government effectiveness and regulatory quality increase the revenue collection capacity of the state, rule of law curtails the ability and freedom of government to spend such resources. These are similar to the sentiments of La Porta et al. (1997).

We find that final consumption expenditure, credit to private sector, external debt, FDI and public GDFI are positively correlated with capitalization. Similar correlations are found between the afore-mentioned variables and turnover except FDI that has no effect on turnover. These findings imply that in Mauritius, private and public sector expenditure increase domestic business and economic confidence. These will positively affect asset markets including stock exchanges as was also found by Ewing (1998).

\subsection{Nigeria}

The results of the correlation analysis for Nigeria are contained in Table 6. Similar to Botswana but unlike Ghana and Mauritius, better control of corruption increases credit to the state and private sector in Nigeria. It also leads to a rise in public sector GDFI. On the other hand, improvements in government effectiveness decrease credit to the private sector and public sector GDFI. In tandem with prior theory, higher regulatory quality increases FDI (Unro, 2007). Rule of law did not have a significant correlation with any of the fiscal or stock market variables.

However, an increase in credit to the state and private sector, external debt and public sector GDFI led to a rise in both capitalization and turnover, emphasizing the findings that fiscal policy impact stock markets (Shah, 1984).

Table 6. Correlation coefficient of panel data variables for Nigeria

\begin{tabular}{lcccccc}
\hline & $\begin{array}{c}\text { Control of } \\
\text { corruption }\end{array}$ & $\begin{array}{c}\text { Government } \\
\text { effectiveness }\end{array}$ & $\begin{array}{c}\text { Regulatory } \\
\text { quality }\end{array}$ & Rule of law & $\begin{array}{c}\text { Stock market } \\
\text { capitalization }\end{array}$ & $\begin{array}{c}\text { Stock market } \\
\text { turnover }\end{array}$ \\
\hline $\begin{array}{l}\text { Lending-deposit spread } \\
\text { Credit to government and } \\
\text { state-owned enterprises/GDP }\end{array}$ & $-0.20(-0.76)$ & $-0.26(-1.03)$ & $0.18(0.70)$ & $-0.02-0.06)$ & $-0.47(-1.98)$ & $-0.48(-2.05)$ \\
$\begin{array}{l}\text { Credit to private sector / } \\
\text { GDP }\end{array}$ & $0.63^{*}(1.83)$ & $-0.40(-1.63)$ & $0.26(1.02)$ & $0.37(1.74)$ & $0.67^{*}(3.37)$ & $0.74 *(4.11)$ \\
$\begin{array}{l}\text { External debt / GDP } \\
\text { Inflation }\end{array}$ & 1.89 & $0.43(1.77)$ & $0.35(1.41)$ & $0.65^{*}(3.21)$ & $0.68^{*}(3.48)$ \\
& $-0.34(-1.33)$ & $0.21(0.82)$ & $-0.10(-0.38)$ & $-0.41(-1.70)$ & $-0.29(-1.13)$ & $-0.26(-0.99)$ \\
$\begin{array}{l}\text { Foreign direct investment }(\%) \\
\text { of GDP) }\end{array}$ & $-0.45(1.89)$ & $-0.25(-0.98)$ & $0.52^{*}(2.30)$ & $0.19(0.74)$ & $0.40(1.22)$ & $0.19(0.71)$ \\
Public GDFI & $0.63 *(3.06)$ & -1.89 & $0.43(1.77)$ & $0.35(1.41)$ & $0.65^{*}(3.21)$ & $0.68^{*}(3.48)$ \\
\hline
\end{tabular}

Source: own computation. Note: Values with * beside them are significant at $5 \%$ significance level.

\subsection{South Africa}

Table 7 presents the results of the correlation analysis for South Africa. While better control of corruption increases the lending-deposit spread, it decreases credit to the state and private sector, external debt and public GDFI. Similar to control of corruption, improved government effectiveness decreases the same afore-mentioned variables excluding the lending-deposit spread. Rather, it narrows the lending-deposit spread. It was found that regulatory quality and rule of law were not significantly correlated with any of the examined fiscal policy and stock market variables. These findings imply that not all governance institutions are essential to stock market development (Senbet \& Otchere, 2006). 
However, capitalization was negatively related to the spread but positively correlated with credit to government as well as the private sector, external debt and public sector GDFI. The same results were found for turnover in South Africa (Park, Kwangoo, \& Ratti, 2000).

Table 7. Correlation coefficient of panel data variables for South Africa

\begin{tabular}{lcccccc}
\hline & $\begin{array}{c}\text { Control of } \\
\text { corruption }\end{array}$ & $\begin{array}{c}\text { Government } \\
\text { effectiveness }\end{array}$ & $\begin{array}{c}\text { Regulatory } \\
\text { quality }\end{array}$ & Rule of law & $\begin{array}{c}\text { Stock market } \\
\text { capitalization }\end{array}$ & $\begin{array}{c}\text { Stock market } \\
\text { turnover }\end{array}$ \\
\hline $\begin{array}{l}\text { Final consumption } \\
\text { expenditure / GDP }\end{array}$ & $0.27(1.06)$ & $-0.01(-0.04)$ & $0.16(0.62)$ & $0.51 *(2.23)$ & $0.31(1.22)$ & $-0.12(-0.46)$ \\
$\begin{array}{l}\text { Lending-deposit spread } \\
\text { Credit to government }\end{array}$ & $0.75^{*}(4.18)$ & -2.106 & $-0.05(-0.19)$ & $0.09(0.34)$ & 2.92 & 2.92 \\
$\begin{array}{l}\text { and state-owned } \\
\text { enterprises / GDP }\end{array}$ & -5.418 & 4.2606 & $0.11(0.41)$ & $0.05(0.18)$ & $0.55^{*}(2.45)$ & $0.74 *(4.18)$ \\
$\begin{array}{l}\text { Credit to private sector } \\
\text { / GDP }\end{array}$ & 3.7446 & 4.2606 & $-0.04(-0.14)$ & $0.12(0.45)$ & $0.63 *(3.05)$ & $0.88^{*}(6.89)$ \\
External debt / GDP & $-0.87 *(-6.65)$ & 6.2128 & $0.11(0.42)$ & $0.10 \mathrm{n}(0.39)$ & $0.69 *(3.54)$ & $0.92 *(8.91)$ \\
$\begin{array}{l}\text { Inflation } \\
\text { Foreign direct }\end{array}$ & $-0.16(-0.62)$ & $-0.16(0.11)$ & $-0.32(-1.25)$ & $-0.43(-1.80)$ & $-0.08(-0.28)$ & $0.22(0.85)$ \\
$\begin{array}{l}\text { investment (\% of GDP) } \\
\text { Public GDFI }\end{array}$ & $-0.07(-0.25)$ & $0.04(0.14)$ & $-0.03(-0.13)$ & $-0.33(-1.30)$ & $-0.14(-0.55)$ & $0.20(0.76)$ \\
\hline
\end{tabular}

Source: own computation. Note: Values with * beside them are significant at $5 \%$ significance level.

\subsection{Fiscal Policy, Governance and Stock Markets in SSA}

We estimate the first regression model (1), that examines whether stock markets are influenced by governance institutions, $G O V_{i}$, and fiscal policy, $F I S C A L_{j}$ as :

$$
\text { MCap }=\alpha_{i}+\sum_{i=1}^{n} \beta_{i} G O V_{i}+\sum_{j=1}^{n} \beta_{j} \text { ISCAL }_{j}+\varepsilon_{i}
$$

Where MCap is the dependent variable (stock market capitalization ratio); $\alpha_{i}$ is the intercept; $\sum_{j=1}^{n} \beta_{j} F I S C A L_{j}$ is the vector of the fiscal policy regression coefficients $\beta_{j}$, and $\varepsilon_{i}$ is the residual term. It summarizes the effect of other pertinent variables not included in (1). The pertinent governance and fiscal policy variables used in the empirical analysis are presented in table $\mathrm{A} 8$ as the results of the regression analysis. The analysis uses a robust regression method in STATA.

Table 8. Regression results for SSA (governance and fiscal policy with stock market capitalization as the dependent variable)

\begin{tabular}{lcccc}
\hline \multicolumn{1}{c}{ Variable } & Regression coefficient & Standard error & T-statistics & P-value \\
\hline Control of corruption & 36.88 & 34.03 & 1.08 & 0.283 \\
Government effectiveness & 225.81 & 38.33 & 5.89 & 0 \\
Regulatory quality & -38.81 & 33.58 & -1.16 & 0.253 \\
Rule of law & -96.22 & 32.77 & -2.94 & 0.005 \\
Final consumption expenditure & 4.48 & 0.69 & 6.51 & 0 \\
Lending-deposit rate spread & 4.34 & 1.8 & 2.41 & 0.019 \\
Credit to public sector by domestic banks & 0.473 & 0.15 & 3.22 & 0.002 \\
\hline
\end{tabular}




\begin{tabular}{|c|c|c|c|c|c|}
\hline Credit to private sector by domestic banks & & -5.82 & 1.1 & -5.28 & 0 \\
\hline External debt & & 0.08 & 0.41 & 0.19 & 0.847 \\
\hline Inflation & & -0.9 & 0.25 & -3.64 & 0.001 \\
\hline FDI & & -0.44 & 0.68 & -0.64 & 0.527 \\
\hline Public GDFI & & -0.23 & 0.19 & -1.18 & 0.245 \\
\hline Constant & & 18.78 & 3.75 & 5 & 0 \\
\hline \multicolumn{6}{|l|}{ Regression diagnostics } \\
\hline $\mathrm{F}(10,58)$ & \multicolumn{5}{|l|}{52.29} \\
\hline P-value of F-stat & 0 & \multicolumn{2}{|r|}{ Akaike Information criterion } & \multicolumn{2}{|l|}{675.93} \\
\hline R-squared & 0.9035 & \multicolumn{2}{|r|}{ Bayesian criterion } & \multicolumn{2}{|l|}{704.98} \\
\hline Adjusted R-squared & 0.88 & \multicolumn{2}{|r|}{ Number of observations } & 69 & \\
\hline
\end{tabular}

Source: own computation.

Table 8 presents the results of our first regression model and it shows that government effectiveness significantly impacts capitalization. The results show a positive correlation between state effectiveness and stock market development/value. This implies that as the state becomes more efficient, stock market value rises. One possible explanation is that in SSA bourses, a high percentage of traded financial instruments are treasuries. Effective state institutions give consumers the confidence of the value of the treasuries resulting in high demand. As an added effect, confidence in other financial instruments will rise leading to an overall positive effect on the economy. Hence, all things being equal, a more effective and efficient government should increase the confidence and demand for such securities (see Allen, Otchere and Senbet, 2011 for similar conclusions).

The results further show that improvements in the rule of law led to a fall in capitalization. We attribute this effect to be due to the possibility that better independence of the rule of law allows the market to correct itself and improve (Applegarth, 2004). Consequently, if a SSA stock market has high capitalization as a result of one or two listed firms which have not yet disclosed losses, bad business strategy or inappropriate corporate governance structures, strict application of the law after disclosure or the media revealing such information could lead to a delisting and/or a fall in market capitalization. An instance of this occurred in 2012, when the Central Bank Governor of Nigeria sanctioned about 10 large banks due to their inappropriate business relationships with some of their borrowers, which eventually led to bad debts, non-payment of the borrowed funds in the midst of a fragile banking system of the country. Although this practice had been going on for several years undisclosed, after the punitive actions and sanctions instituted by the Governor, the capitalization of the Nigeria Stock Exchange fell to its true value. Prior to the disclosure of such practices, the NSE was overvalued (Nigeria Stock Exchange, 2010). Reforms by the Central Bank heightened investor fears at first but eventually increased their confidence in the economy as the Chief Executives and Managers of such financial institutions were punished. This sent a signal to others that if they undertook equivalent nefarious activities, they would be similarly disciplined.

Final consumption expenditure is positive and significant, implying that spending by the state and other economic agents increases consumption of goods and services produced by listed companies. In reality, such expenditure by economic agents increases the revenues, profits and capitalization of these listed companies. The end result would be a general rise in stock market capitalization. Also, increased domestic spending may be underpinned by high business and economic confidence. Such expectations would increase investor confidence in the concerned economy. Combined together, these factors would raise capitalization as concluded by Chatziantoniou et al., (2013) in their study of stock market responses to monetary and fiscal policy.

Other positive and significant variables in our results include lending-deposit rate spread and market capitalization. An explanation of this positive relationship between these two variables may be that an increase in the margin may increase bank lending. Such a wide margin is a price signal to banks that there are more profits to be earned. Consequently, they will lend more. Despite the adverse effects this may lead to, it may increase economic activity and stock market capitalization. This is not surprising as Allen et al. (2011) and Okeahalam (2005) find that in general, African financial systems have inefficient banking industries and large spreads They also show that a rise in domestic bank credit to the state increases capitalization. One way this may happen is, as more treasury securities are issued, the state raises more debt while at the same time increasing stock market 
values. This is quite possible as almost $50 \%$ of securities traded on SSA are treasuries. Furthermore, Stiglitz and Rashid (2013) find that such securities are mostly purchased by institutional investors, most of which are domestic banks. Moreover, banks will only lend to the state if and only if they are confident that government will and can pay. They will factor in the capacity, character and collateral of the public sector. These determinants will be high in an economy with some basic level institutional quality. Unlike credit to government, increased lending to the private sector decreases market capitalization. This may imply that bank credit and issuing equity securities via stock markets are substitutes. Firms in SSA may be heavily dependent on one of these sources of funding.

Inflation has adverse effects on capitalization. It distorts and erodes asset values as it increases in SSA. This should be a case for concern as SSA countries have one of the highest inflation rates (Patti, Kwangoo, \& Ratti, 2000). The constant term is also significant. This may indicate that there are certain unexamined initial factors that also determine market capitalization. The high adjusted R-Squared, Akaike information criterion and Bayesian criterion indicate that the regression model used explains a high portion of variations in stock market capitalization (Greene, 2005).

\subsection{Business Regulations, Fiscal Policy and Stock Markets in SSA}

In equation (2), we replace the vector of governance indicators with that of business regulations. We exclude governance indicators because they are highly correlated with business regulations: such a relationship is indicative of multi-collinearity (see Gujarati, 2005). We estimate the second model:

$$
\text { MCap }=\alpha_{i}+\sum_{i=1}^{n} \beta_{i} B U S_{-} R E G_{i}+\sum_{j=1}^{n} \beta_{j} F_{S C A L_{j}}+\varepsilon_{i}
$$

Where $\sum_{i=1}^{n} \beta_{i} B U S_{-} R E G_{i}$ denotes the vector of different business regulation variables, $B U S_{-} R E G_{i}$ and their respective regression coefficients, $\beta_{i}$. The pertinent business regulations and fiscal policy variables used in the empirical analysis are listed in table 8 . The same table also presents the results of the regression analysis using a robust regression method in STATA.

Table 9. Regression results for SSA (business regulations and fiscal policy with market capitalization as dependent variable)

\begin{tabular}{|c|c|c|c|c|}
\hline Variable & Regression coefficient & Standard error & T-statistics & P-value \\
\hline Closing a business & -0.44 & 0.193 & -2.272 & 0.027 \\
\hline Starting a business & -0.39 & 0.134 & -2.895 & 0.006 \\
\hline Trading across borders & 0.12 & 0.139 & 0.868 & 0.389 \\
\hline Enforcing contracts & -0.5 & 0.214 & -2.531 & 0.023 \\
\hline Inflation & -0.14 & 0.601 & -0.229 & 0.82 \\
\hline Lending rate-Deposit rate spread & 1.65 & 1.947 & 0.849 & 0.4 \\
\hline Foreign direct investment & 4.64 & 1.683 & 2.759 & 0.008 \\
\hline $\begin{array}{l}\text { Credit to government and state-owned } \\
\text { Enterprises }\end{array}$ & 0.14 & 1.522 & 0.921 & 0.362 \\
\hline Constant & 98.07 & 13.358 & 7.342 & 0 \\
\hline Regression diagnostics & & & & \\
\hline $\mathrm{F}(8,51)$ & 18.56 & & & \\
\hline P-value of F-stat & \multicolumn{2}{|c|}{ Akaike Information criterion } & 580.03 & \\
\hline R-squared & \multicolumn{2}{|c|}{ Bayesian criterion } & 598.88 & \\
\hline Adjusted R-squared & \multicolumn{2}{|c|}{ Number of observations } & 60 & \\
\hline
\end{tabular}

The business regulation variables may be classified into 10 different categories, namely: starting a business, dealing with licenses, employment laws, registering property, getting credit, protecting investors, paying taxes, 
trading across borders, enforcing contracts and closing a business. Each of these indicators may be further disaggregated into 5 to 7 different indicators. For instance, the starting a business main indicator comprises of number of procedures to register a limited liability company, time to register in number of days, cost of registering as a percentage of per capita income and the required minimum capital. As an example, it takes only 6 days to register a limited liability firm in Mauritius while it takes almost 108 days in Botswana. Some of these were found to be highly correlated. As such, only those that were uncorrelated were included in (2). It is worth noting before discussing the results in table A1 that an increase in the value or rank of each business regulation indicator implies a worsening of such laws and policies. This increases the cost and difficulty of doing business in the country concerned (World Bank, 2013c).

The results in Table 9 indicate that three main business regulations affect capitalization and they are starting $a$ business; closing a business; and enforcing contracts. When such laws are inappropriate or deteriorate, they decrease capitalization. This implies that it is expensive and difficult to start a limited liability firm in the first place. Yet, it is only such firms that can be listed on the stock exchange.

It is estimated that in Ghana, more than $70 \%$ of all business enterprises are in the informal sector. This is the case in most of SSA. With a low number of private limited liability firms in Africa, there will be an even smaller number listing on the stock market. Furthermore, market activity requires that it be easy or inexpensive for a firm to exit or transform itself during the creative destruction process when a particular industry is unprofitable. However, the related costs of winding up are so high in SSA that a high number of firms are 'stuck in limbo'. They cannot alter their structures quick enough to take advantage of market turning points (Agyeman-Duah, 2008). For instance, the bankruptcy regulations of most SSA countries do not include similar provisions as those found in the chapter 11 bankruptcy laws of the United States of America. The chapter 11 rules allow a firm to file for bankruptcy, continue operations, negotiate with creditors and alter its financial and ownership structure with a view to returning to full operations as a going concern but with less outstanding debt (Djankov, McLiesh, \& Shelifer, 2007).

In Africa, the general rule is for a firm to cease as a going concern after filing for bankruptcy. The company no more exists thereafter. Furthermore, it may take as long as 4.5 years just to wind up and cost as much as $22 \%$ of the estate. Only in Botswana is the recovery rate as high as $60 \%$. It can be as low as $14.6 \%$. The average recovery rate for limited liability firms closing up in the sampled countries was $33.25 \%$. These conditions do not encourage market flexibility.

Our results also indicate that the costs and difficulties of enforcing contracts in SSA have adverse effects on capitalization. There exist a negative correlation between our business regulation variables and stock market capitalization. For instance, in Kenya about 40 procedures are required to enforce contracts related to limited liability companies. It could take as much as 730 days. In relation to ensuring payment of borrowed funds, it could cost as much as half of the amount lent. The average for the sampled countries was 30 procedures, 501 days and $26.41 \%$ of borrowed funds. Only a few SSA countries have significantly improved their business and related regulations thus improving the market environment, unlike the vast majority (McDonald, Calvin, \& Schumacher, 2007). The SSA countries in the examined sample in this study are among the more relatively open and reformed nations with market economies.

In terms of FDI, we find that it significantly increases capitalization. On the one hand, this is encouraging because it implies that capital flows stimulate stock market development. However, on the other hand, this is disturbing as it implies that there are challenges for SSA countries to raise their own capital and funds to finance their development and growth. More than $60 \%$ of Africans fall below or on the poverty line. Income per capita is significantly low. Furthermore, with a large section of economic activity in the informal sector for mainly subsistence purposes, domestic investments per capita are still relatively low. For instance, excluding SA, more than $70 \%$ of SSA stock market activity is by foreign institutional investors working in Africa. Security trading on behalf of individuals in these markets is mostly for the small middle class. A number of listed companies on SSA stock markets are independent subsidiaries of foreign firms. Others were formerly private foreign-owned legal entities that later list on African exchanges. Such is also defined as FDI. Also, these foreign investments stimulate capitalization as foreign private firms have the resources to enter into industries and ventures requiring large initial capital. Such industries are usually those with several strategic linkages. These make it possible for other firms to expand and later list on African stock exchanges (Law \& Habibullah, 2009). A case in point is the arrival of several downstream and upstream oil firms in Ghana after the discovery of commercial quantities of oil. This significantly increased FDI inflows. In 2011, Tullow Oil listed on the Ghana Stock Exchange as the firm benefited from prior FDI by firms in and outside the oil industry. Tullow Oil, for instance, began operations in the Ghanaian economy as a privately-owned foreign firm (see Tullow Oil Ghana Limited, 2013). 


\section{Conclusions and Recommendations}

This study examined how the state affects stock markets development in SSA by analyzing the determinate factors that influence stock market capitalization. It does this by analyzing three main determinants: business regulations; governance; and fiscal policy. In terms of governance, government institution's effectiveness and rule of law were found to affect capitalization positively. Final consumption expenditure; credit to both state and private sector; the lending-deposit spread; and inflation; all had impact on stock market capitalization. With respect to business regulations and fiscal policy, it finds that starting a business; closing it; and enforcing contracts were most relevant.

This study highlights the importance of the state in encouraging stock market development in SSA. The state needs to develop appropriate market laws to outline the "rules of the game" for the market place. Fiscal policy was found to be a strong factor to stimulate stock markets on the continent. These findings imply that all three policy tools in our study are very important: that is business regulations, governance and fiscal policy. Inattention to any of these, we believe, will cause a stagnation of stock market development in SSA. In more democratic SSA countries, governments usually focus more and spend greater resources on improving governance institutions because such limitations are more apparent with growing press and media freedom. However, it usually takes one economic year or more to determine the effects of a specific fiscal policy. Consequently, it takes more time to address such shortcomings. With regard to business regulations, such concerns are usually reported without much actual redress by the state. One of the reasons for this is that critical infrastructure such as energy, health facilities, roads and portable water, are felt to be much more pressing needs requiring quicker attention. For instance, with the high child mortality rates in most of SSA, most citizens would prefer their respective governments to address that as a matter of urgency as compared to developing appropriate business regulations.

One recommendation emanating from the findings herein is that African governments need to develop appropriate regulations to address existing policy gaps. In some SSA countries, the market places are chaos environments because there are no appropriate 'rules of the market' and where there are, they are not enforced or implemented. This is mostly the case of countries coming out from civil and ethnic strife, natural catastrophes and wars. Others have dictatorial regimes not interested in enacting laws and policies to develop their economies (Anayiotos \& Toroyan, 2009).

These results emphasize the critical importance of business and corporate regulations affecting the activities, creation, operations and winding up of such legal entities. This implies that SSA governments should develop appropriate business and investor-friendly policies to stimulate their economies. For instance, with more than 70\% of existing business ventures located in the informal sector in Africa, there is a need to first migrate such enterprises to the formal sector and then later onto the national stock exchange where they can access funds from domestic and international investors. As it is now, only a small proportion of informal ventures eventually become limited liability companies. A large proportion of them prefer to become sole proprietorships (Okeahalam, 2005). One of the reasons for this is that the requisite formalities and procedures for such proprietorships are less costly and cumbersome. If the same processes for limited liability entities were similarly less expensive and burdensome, perhaps a significantly larger number of informal ventures would opt to become limited liability firms. During election campaigns in most SSA countries, it is common to hear contesting parties trumpeting their successes in developing more accountable and transparent governance, infrastructure and health facilities. Little or nothing is said about developing an appropriate regulatory environment for firms.

Additionally, this study demonstrates that not all governance institutions and business regulations are critical to enhancing stock market development. The paper finds that there are some which are most vital such as the rule of law and the regulations for starting a business, most especially a limited liability firm. This implies that rather than expending significant resources on developing non-critical institutions, focusing on the most vital regulations and policies such as the rule of law would be most beneficial to financial market development. This paper does not suggest the selective development of governance institutions and business regulations. Rather, it recommends that all appropriate institutions, policies and regulations should be developed but the most critical to financial sector and stock market development should have greater emphasis.

\section{References}

Afful, K. B., \& Okeahalam, C. C. (2006). Stock markets, development indicators and investment in Sub-Saharan Africa. African Review of Money, Banking and Finance, 1, 39-60.

Afonso, A., \& Sousa, R. M. (2011). What are the effects of fiscal policy on asset markets? Economic Modelling, 28, 1871-90. http://dx.doi.org/10.1016/j.econmod.2011.03.018 
Afonso, A., \& Sousa, R. M. (2012). The macroeconomic effects of fiscal policy. Applied Economics, 44, 44394454. http://dx.doi.org/10.1080/00036846.2011.591732

Agyeman-Duah, I. (2008). An economic history of Ghana: Reflections on a half-century of challenges and progress. Ayebia Clarke Publishing ltd., Accra, Ghana.

Akitoby, B., \& Stratmann, T. (2008). Fiscal policy and financial markets. Economic Journal, 118, 1971-1985. http://dx.doi.org/10.1111/j.1468-0297.2008.02198.x

Ali, S. M., \& Hasan, M. A. (2003). Is the Canadian stock market efficient with respect to fiscal policy? Some vector autoregression results. Journal of Economics and Business, 45(1), 45-59.

Allen, F., Otchere, I., \& Senbet, L. W. (2011). African financial systems: A review. Review of Development Finance, 30(3), 1-35. http://dx.doi.org/10.1016/j.rdf.2010.10.002

Anayiotos, G. C., \& Toroyan, H. (2009). Institutional factors and financial sector development: Evidence from Sub-Saharan Africa. International Monetary Fund Working Paper, WP/09/258, International Monetary Fund, Washington DC., USA. $\quad$ Retrieved from http://www.researchgate.net/...Institutional_Factors_and_Financial_Sector_Dev...

Applegarth, P. V. (2004). Capital market and financial sector development in Sub-Saharan Africa: A report of the africa policy advisory panel. Center for strategic and International Studies, Washington, DC., USA. Retrieved from http://www.csis.org/files/media/csis/pubs/0405_capitalmarkets.pdf

Ardagna, S. (2009). Financial markets' behaviour around episodes of large changes in the fiscal stance. European Economic Review, 53, 37-55. http://dx.doi.org/10.1016/j.euroecorev.2008.07.003

Ardagna, S., \& Lusardi, A. (2008). Explaining international differences in entrepreneurship. The role of individual characteristic and regulatory constrain. NBER working paper Vol. 14012 Cambridge, MA.

Asiedu, F. K., \& Afful, K. B. (2013). Fiscal policy, interest rate spreads and stock markets in Sub-Saharan Africa, Business and Economics Journal, BEJ-81, 1-10. Retrieved from http://astonjournals.com/manuscripts/Vol2013/BEJ-81_Vol2013.pdf

Baltagi, B. H., Demetriades, P., \& Law, S. H. (2009). Financial development and openness: Evidence from panel data. Journal of Development Economics, 89, 285-296. http://dx.doi.org/10.1016/j.jdeveco.2008.06.006

Beck, T., Demirguc-Kunt, A., \& Levine, R. (2003). Law, endowments, and governance. Journal of Financial Economic, 70(2), 137-181. http://dx.doi.org/10.1016/S0304-405X(03)00144-2

Chatziantoniou, I., Duffy, D., \& Filis, G. (2013). Stock market responses to monetary and fiscal policy shocks: $\begin{array}{lllll}\text { Multi-country } & \text { evidence. } & \text { Economic } & \text { Modeling, } & \text { 30, }\end{array}$ http://dx.doi.org/10.1016/j.econmod.2012.10.005

Cherif, M., \& Gadzar, K. (2010). Macroeconomic and institutional determinants of stock market development in the MENA region: New results from a panel data analysis. International Journal of Banking and Finance, 7(1), 139-159. Retrieved from http://epublications.bond.edu.au/cgi/viewcontent.cgi?article=1024\&context=ijbf

Dahou, K., Omar, I. H., \& Pfister, M. (2009). Deepening African financial markets for growth and investment (pp 11-12). Background Paper Prepared for the Ministerial and Expert Roundtable of the Africa Investment Initiative of the New Economic Partnership for African Development and Organization for Economic Cooperation and Development, November. Retrieved from http://www.mfw4a.org/documents-details/deepening-african-financial-markets-for-growth-and-investment.h tml

Darrat, A. F. (1988). On fiscal policy and the stock market. Journal of Money, Credit and Banking, 20, 353-363. http://dx.doi.org/10.2307/1992261

Djankov, S., McLiesh, C., \& Shleifer, A. (2007). Private credit in 129 countries. Journal of Financial Economics, 84(2), 299-329. http://dx.doi.org/10.1016/j.jfineco.2006.03.004

Economic Development in Africa Report. (2012). Structural transformation and sustainable development in Africa. United Nation Conference on Trade and Development, New York and Geneva.

Ewing, B. T. (1998). The impact of federal budget deficits on movements in the stock market: Evidence from Australia and France. Applied Economics Letters, 5, 649-651. http://dx.doi.org/10.1080/135048598354348

Fage, J. D. (2001). A history of Africa (4th ed.). United Kingdom: Routledge. 
Ghana Revenue Authority (GRA). (2013). Tax incentives. Ghana Revenue Authority. Retrieved from http://www.gra.gov.gh/tax_incentives.pdf

Girma, S., \& Shortland, A. (2008). The political economy of financial development. Oxford Economic Papers, 60(4), 567-596. http://dx.doi.org/10.1093/oep/gpm040

Greene, W. H. (2005). Econometric analysis. New Jersey, USA: Pearson Education Incorporated.

Gujarati, D. (2005). Basic econometrics (4th ed.). USA: McGraw-Hill Companies Incorporated. Retrieved from http://www.gobookee.org/essentials-of-econometrics-gujarati/

Holder, R. (2007). Institutions, trade and the political economy of financial development. Working paper No. 2007/27, Swiss National Centre of Competence in Research. Retrieved from http://www.hse.ru/data/106/482/1225/Sept\%209\%20Law\%20and\%20Finance.pdf

Human Development Report (HDR). (2006). Beyond scarcity-power, poverty and the global water crises. United Nations Development Programme, New York, USA. Retrieved from http://hdr.undp.org/hdr2006/pdfs/report/HDR06-complete.pdf

Human Development Report (HDR). (2011). Sustainability and equity: A better future for all. United Nations Development Programme, New York, USA. Retrieved from http://hdr.undp.org/en/reports/global/hdr2011/

Irving, J. (2000). Africa's struggling stock exchanges, boost to economic development or costly irrelevance? Africa Recovery, 14, 25-28.

Jansen, D. W., Li, Q., Wang, Z., \& Yang, J. (2008). Fiscal policy and asset markets: A semiparametric analysis. Journal of Econometrics, 147, 141-150. http://dx.doi.org/10.1016/j.jeconom.2008.09.007

La Porta, R., Lopez-de-Silanes, F., Sheifer, A., \& Vishny, R. W. (1997). Legal determinants of external finance. Journal of Finance, 53(1), 1131-1155. http://dx.doi.org/10.1111/j.1540-6261.1997.tb02727.x

La Porta, R., Lopez-de-Silanes, F., Sheifer, A., \& Vishny, R. W. (1998). Law and finance. Journal of Political Economy, 106(6), 1131-1150. http://dx.doi.org/10.1086/250042

La Porta, R., Lopez-de-Silanes, F., Sheifer, A., \& Vishny, R. W. (1999). The quality of government. Journal of Law, Economics and Organization, 15(1), 222-279. http://dx.doi.org/10.1093/jleo/15.1.222

Laopodis, N. T. (2009). Fiscal policy and stock market efficiency. Quarterly Review of Economics and Finance, 49(2), 633-660. http://dx.doi.org/10.1016/j.qref.2007.10.004

Law, S. H., \& Habibullah, M. S. (2009). The determinants of financial development: Institutions, openness and financial liberalization. South African Journal of Economics, 77(1), 45-58. http://dx.doi.org/10.1111/j.1813-6982.2009.01201.x

Lee, B. (1992). Causal relations among stock returns, interest rates, inflation, and real activity. Journal of Finance, 42(4), 1591-1603. http://dx.doi.org/10.1111/j.1540-6261.1992.tb04673.x

Lee, U. (1997). Stock market and macroeconomic policies: New Evidence from Pacific Basin Countries. Multinational Finance Journal, 1, 273-289. Retrieved from http://www.usc.es/economet/reviews/aeid436.pdf

McDonald, C., \& Schumacher, L. (2007). Financial deepening in Sub-Saharan Africa: Empirical evidence on the role of creditor rights protection and information sharing. Working Paper 07/203, International Monetary Fund. Retrieved from http://cid.bcrp.gob.pe/biblio/Papers/IMF/2007/agosto/wp07203.pdf

Mountford, A., \& Harald, U. (2009). What are the effects of fiscal policy shocks? Journal of Applied Econometrics, 24, 960-992. http://dx.doi.org/10.1002/jae.1079

Ncube, M. (2007). Financial service and economic development in Africa. Journal of Africa Economics, 16(AERC supplement 1), 13-57. http://dx.doi.org/10.1093/jae/ejm025

Nigeria Stock Exchange. (2010). Annual Report 2009. Nigeria Stock Exchange, Nigeria. Retrieved from http://www.nse.com

Okeahalam, C. C. (2005). Institutions and financial market development in the MENA region. Progress in Development Studies, 5(4), 310-328. http://dx.doi.org/10.1191/1464993405ps119oa

Otchere, I. (2006). Stock exchange self-listing and value effects. Journal of Corporate Finance, 12(5), 926-953. http://dx.doi.org/10.1016/j.jcorpfin.2006.02.003

Park, K., \& Ronald, A. R. (2000). Real activity, inflation, stock returns, and monetary policy. The Financial 
Review, 35, 59-78. http://dx.doi.org/10.1111/j.1540-6288.2000.tb01414.x

Pistor, K., Raiser, M., \& Stanislaw, G. (2000). Law and finance in transition economies. Economics of Transition, 8(2), 325-368. http://dx.doi.org/10.1111/1468-0351.00047

Razin, A. (1990). Fiscal policies and the integrated world stock market. Journal of International Economics, 29(3), 109-122. http://dx.doi.org/10.1016/0022-1996(90)90066-U

Senbet, L., \& Otchere, I. (2006). Financial sector reforms in Africa: Perspectives on issues and policies. Annual World Bank conference on development economics: growth and integration.

Senbet, L., \& Otchere, I. (2008). Beyond banking: Developing markets, african finance for the $21^{\text {st }}$ century, high-level seminar organized by the IMF Institute in collaboration with the joint Africa institute. Session III, Tunis. Tunisia, March 4-5. Retrieved http://www.rhsmith.umd.edu/faculty/lsenbet/lemmas\%20papers/Afican\%20Stock\%20Markets.pdf

Shah, A. (1984). Crowding out, capital accumulation, the stock market, and money-financed fiscal policy. Journal of Money, Credit, and Banking, 16, 461-473. http://dx.doi.org/10.2307/1992184

Singh, A. (1999). Should Africa promote stock market capitalization? Journal of International Development, 11(3), 343-365. http://dx.doi.org/10.1002/(SICI)1099-1328(199905/06)11:3<343::AID-JID593>3.0.CO;2-Q

Standley, S. (2010). What are the determinants of financial market development in Sub-Saharan Africa? Private Sector \& Development, 5, 17-19. $\quad$ Retrieved from http://enkocapital.com/downloads/Private-Sector-Development.pdf

Stiglitz, J., \& Rashid, H. (2013). Sub-Saharan Africa's eurobond borrowing spree gathers pace. The Guardian. Retrieved from http://www.goodreads.com/author/show/6426.Joseph_E_Stiglitz/blog

Tullow Oil Ghana Limited. (2013). Annual Reports 2013. Tullow Oil Ghana Limited. Retrieved from http://www.tullowoil.gh.com

Unro, L. (2007). Stock returns and fiscal policy: Additional international evidence. Indian Journal of Economics and Business, 6(2), 241-255.

World Bank. (2013a). Africa development indicator database. World Bank, Washington, USA.

World Bank. ( 2013b). World development indicators. World Bank, Washington, USA.

World Bank. (2013c). World governance indicators. World Bank, Washington, DC., USA. Retrieved from http://databank.worldbank.org/data/home.aspx

Yartey, C. A., \& Adjasi, C. K. (2007). Stock market development in Sub-Saharan Africa: Critical issues and challenges. International Monetary Fund Working Paper WP/07/209, International Monetary Fund, Washington, USA. Retrieved from http://www.imf.org/external/pubs/ft/wp/2007/wp07209.pdf 


\section{Appendix}

Appendix 1. Correlation analysis of governance and business regulations (tests for multicollinearity)

\begin{tabular}{|c|c|c|c|c|c|c|}
\hline Indicator & $\begin{array}{l}\text { Control of } \\
\text { corruption }\end{array}$ & $\begin{array}{l}\text { Government } \\
\text { effectiveness }\end{array}$ & $\begin{array}{l}\text { Political stability } \\
\text { and absence of } \\
\text { terrorism }\end{array}$ & $\begin{array}{c}\text { Regulatory } \\
\text { quality }\end{array}$ & Rule of law & $\begin{array}{c}\text { Voice and } \\
\text { accountability }\end{array}$ \\
\hline Starting a business & $-0.68 *(-9.67)$ & $-0.71 *(11.07)$ & $-0.60 *(-7.17)$ & $-0.71 *(-10.91)$ & $-0.71 *$ & $-0.68 *(-9.68)$ \\
\hline Dealing with & $-0.58 *(-6.54)$ & $-0.61 *(-7.51)$ & $-0.41 *(-3.72)$ & $-0.63 *(-7.97)$ & $-0.60 *(-7.22)$ & $-0.58 *(-6.69)$ \\
\hline Employment laws & $-0.58 *(-6.75)$ & $-0.62 *(-7.71)$ & $-0.54 *(-5.86)$ & $-0.59 *(-6.99)$ & $-0.60 *(-7.14)$ & $-0.60 *(-7.13)$ \\
\hline Registering & $-0.18(-1.43)$ & $-0.20(-1.58)$ & $-0.10(-0.75)$ & $-0.24(-1.97)$ & $-0.21(-1.70)$ & $-0.13(-0.97)$ \\
\hline Getting credit & $-0.39 *(-3.48)$ & $-0.39 *(-3.52)$ & $-0.36^{*}(-3.14)$ & $-0.43 *(-4.02)$ & $-0.41 *(3.78)$ & $-0.36 *(-3.13)$ \\
\hline Protecting investors & $-0.50 *(-5.12)$ & $-0.54 *(-5.84)$ & $-0.49 *(-4.89)$ & $-0.54 *(-5.86)$ & $-0.56 *(-6.15)$ & $-0.52 *(-5.49)$ \\
\hline Paying taxes & $-0.19(1.49)$ & $-0.20(-1.62)$ & $-0.10(-0.77)$ & $-0.22(-1.78)$ & $-0.20(-1.57)$ & $-0.16(-1.22)$ \\
\hline Trading across & $-0.20(-1.61)$ & $-0.18(-1.44)$ & $-0.05(-0.39)$ & $-0.23(-1.84)$ & $-0.20(-1.57)$ & $-0.19(-1.51)$ \\
\hline Enforcing contracts & $-0.75^{*}$ & $-0.77 *(-14.44)$ & $-0.64 *(-8.17)$ & $-0.77 *(-14.44)$ & $-0.76^{*}$ & $-0.76^{*}(-13.56)$ \\
\hline Closing a business & $-0.77 *$ & $-0.81 *(-17.75)$ & $-0.67 *(-9.15)$ & $-0.80 *(-16.50)$ & $-0.82 *$ & $-0.81 *(-18.16)$ \\
\hline
\end{tabular}

Source: own computation. Note: Values with * beside them are significant at $5 \%$ significance level.

\section{Copyrights}

Copyright for this article is retained by the author(s), with first publication rights granted to the journal.

This is an open-access article distributed under the terms and conditions of the Creative Commons Attribution license (http://creativecommons.org/licenses/by/3.0/). 